\title{
REMEDIATION OF A RAILWAY EMBANKMENT USING GEOCELLS AND DEEP SOIL MIXING - A NUMERICAL ANALYSIS
}

\author{
JAN ŠTEFAŇÁK ${ }^{a, *}$, JOSEF VAŠINA ${ }^{b}$ \\ a Brno University of Technology, Faculty of Civil Engineering, Institute of Geotechnics, Veveři 331/95, Brno, \\ Czech Republic \\ ${ }^{b}$ WALTEC GDS, s.r.o., Masarykova 1355, Blansko, Czech Republic \\ * corresponding author: stefanak.j@fce.vutbr.cz
}

\begin{abstract}
Progressive settlement of the embankment under the railway track near Ždár nad Sázavou, the Czech Republic, has been observed for many years. Immediate improvement was needed to secure the safety of the traffic and to increase the travel speed of the track. The reconstruction work consisted of deep soil mixing. Also, a load spreading geocell reinforced mattress was designed. The evaluation of the proposed solution by means of numerical modelling and associated laboratory testing is described in the paper.
\end{abstract}

KEYWORDS: Geocell, deep soil mixing, remediation, numerical modelling.

\section{INTRODUCTION}

The purpose of the remediation work is the reconstruction of both an embankment and the railway track near the railway station Ždár nad Sázavou, Czech republic. The railway of interest is a national railway included in the European Transport Network TEN-T. The height of the embankment is cca $5.5 \mathrm{~m}$. The unsatisfactory condition of about 320 metres of the embankment was identified during the preliminary walk-over survey. Horizontal deformation of the crowns of the embankment body was observed. Tilting of the traction line columns were observed in some places also, as can be seen in Figure 1. The owners of the regional railway infrastructure proved the necessity of repeated tamping of the track ballast under railway tracks due to the disintegration of the geometrical position of the track rails [1]. Hence, the main purpose of both remediation and increasing the width of the embankment is to increase stability and to ensure the safety of railway transport. A consequent effect is an increase of the railway traffic speed. The measures designed to achieve the stated goals are described in detail later in the paper.

The area concerned is built of metamorphic rocks of the Moravian branch of the Moldanubian in terms of geological structure. Metamorphic rocks in the subsoil of the railway embankment are heavily weathered and to a considerable depth. The rock eluvium has the character of clay and dusty sand. The eluvium is covered with a layer of fill and or Quaternary clay of variable thickness. Clayey eluvium and clay are insulators from hydrogeological point of view. The clayey sandy and sandy eluvium is only slightly waterlogged. The slope of the groundwater level and the direction of groundwater flow is to the N, NNE and NE, towards the Sázava river. Climatic conditions in the area of interest are characterized by freezing depth $h_{p r}=1.1 \mathrm{~m}$.

\subsection{Results of THE GeOteChNiCAL SURVEY OF THE EMBANKMENT}

Evidence of instability, visible to the eye, was found in both the railway tracks and the embankment. Tilting of traction line columns and deformation of the embankment crown were observed during the preliminary investigation and walk-over survey. Based on the results of the preliminary investigation, the strategy for a detailed survey of the embankment body was established. The survey was conducted in three typical cross-sectional profiles. Combinations of trial pits, core boreholes, and dynamic penetration tests were performed in each profile. The results of penetration tests were evaluated according to [2]. The probes were evenly distributed at the base of the embankment body, at the top (in the axis of the two parallel rail tracks) and in the crowns on both sides of the embankment. Based on the results of dynamic probing, the relative density of soil into the depth of $3.3 \mathrm{~m}$ was recognized as loose to medium-dense. The soil sample was classified according to EN ISO 14688-2 as siSa. The percentages of the individual soil fractions were $4 \%$ of fine grains, $21 \%$ of sand and $62 \%$ of sand and $13 \%$ gravel. An admixture of slag by-products was found in the samples also. The material ranges from poorly permeable to permeable. Probes at the foot of the embankment body and in the axis of the embankment crown could not be performed due to an abundant presence of cable routes.

\subsection{Proposed REMEdiation WORK}

The following sequence of remediation measures was proposed, based on results of the conducted surveys: 

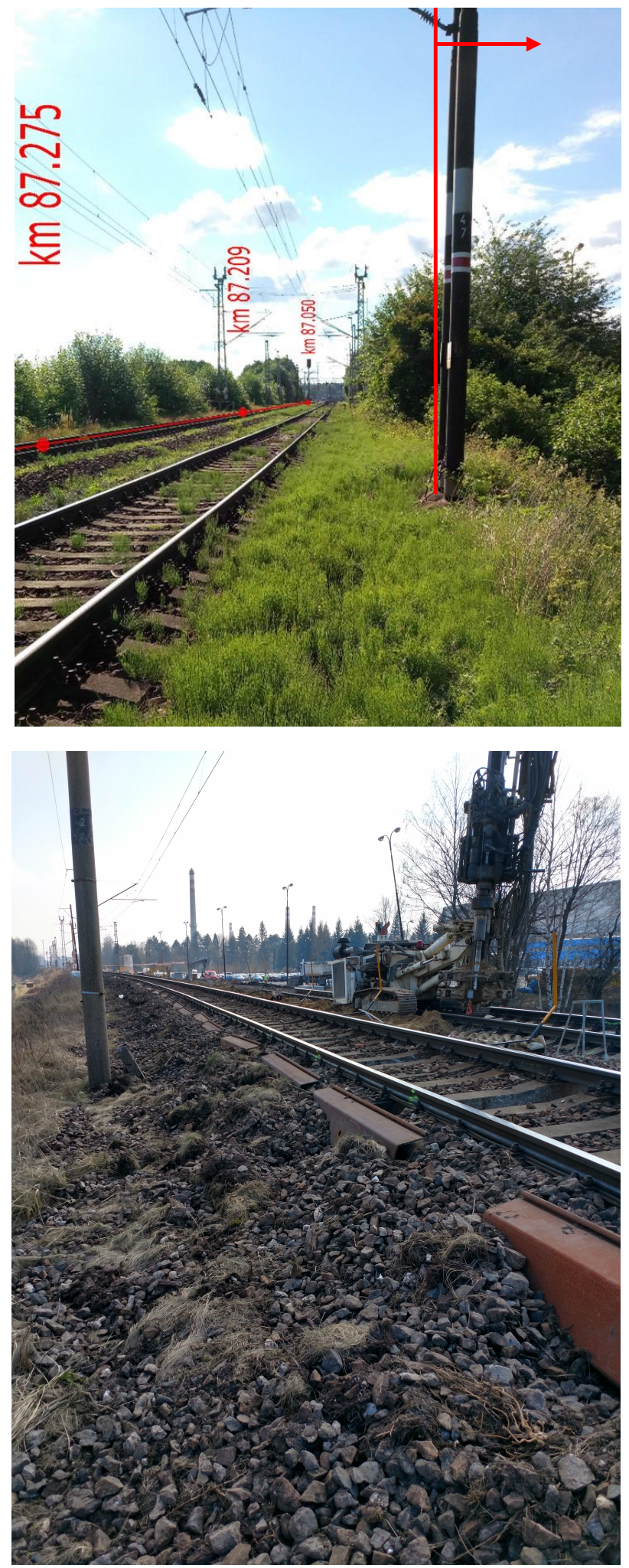

Figure 1. Condition of the railway before reconstruction: tilting of the traction line columns (top) and Temporary measures against disintegration of the track rail geometrical position(bottom).

(1.) Removal of the top part of the embankment along its entire length to a depth of approximately $1.6 \mathrm{~m}$ below the current sub-ballast layer.

(2.) Construction of the Deep Soil Mixing (DSM) columns evenly distributed in the embankment. The purpose of DSM columns is to increase the stiffness of the embankment and to help transfer the traffic load from the rail through the embankment body to the subgrade formed by competent weathered gneiss rock.

(3.) Building of a gabion wall situated at the foot of the embankment body. The height of the wall varies between $1.0 \mathrm{~m}$ and $3.0 \mathrm{~m}$, according to the actual height of the embankment in specific sections. The purpose of the gabion walls is to improve a currently too steep geometry of embankment slopes and to eliminate the vertical deformation of the embankment due to the traffic loading.

(4.) Construction of the geocell mattress filled with crushed stone. The mattress is constructed above the hi-strength single-axial geogrid and geomembrane that cover the heads of DSM pillars.

\section{NuMERICAL ANALYSIS}

A relatively high number of technologies and structural elements is combined in the above described remediation measures. Hence, it was decided to use the Finite Element Method (FEM) as a tool for assessing the effect of designed measures on the stability and deformation of the embankment. The Plaxis 2D package was used for simulation of the development of the stress-strain state in the embankment, with respect to the sequence of the remediation work phases. 15node finite elements were used for modelling the soil, which approximates the deformation by quartic polynomials. "Plastic" and "safety" types of calculations were performed. The input values of the properties of the soil materials forming the embankment and the subgrade were determined on the basis of the results of conducted laboratory tests and in-situ tests. Approaches for transforming each component of the remediation measures into a plane strain numerical model are described in the following paragraphs.

\subsection{Modelling of DeEP SOIL IMPROVEMENT}

The installation of Deep Soil Mixing (DSM) pillars with a diameter of 0.6 meters with axial distance 1.2 metres in the longitudinal direction is one of the key components of the proposed remediation measures. The process of column mixing is captured in Figure 6. Adequate data from the literature [3] were used to determine the strength and deformation properties of the final product of the DSM technique, the soil-cement composite. The line of columns is represented by the virtual wall in the $2 \mathrm{D}$ numerical model. The equivalent modulus of elasticity of the wall was calculated as the weighted average of the modulus of elasticity of the column $E_{c o l}=2000 \mathrm{MPa}$ [3] and of the modulus of the soil between the pillars in the longitudinal direction $E_{\text {soil }}=6 \mathrm{MPa}$. The principle of calculation of the equivalent modulus of elasticity 
of the wall summarised in 4 is described by equations (1)- 3) and schematically illustrated in Figure 2. Symbol $A_{c o l}$ represents the cross-sectional area of the DSM column and the $A_{r}$ the area of the virtual wall.

$$
\begin{gathered}
r_{c o l}=\frac{A_{c o l}}{A_{r}}=\frac{A_{c o l}}{A_{c o l}+A_{\text {soil }}} \\
r_{\text {soil }}=1-r_{c o l} \\
E_{e q}=\left(r_{c o l} E_{c o l}\right)+\left(r_{\text {soil }} E_{\text {soil }}\right)
\end{gathered}
$$

The uniaxial compressive strength of the DSM column composite material was estimated according to [3] as $\sigma_{c}=3.5 \mathrm{MPa}$. The methods proposed by [5] were used then for the transformation of the uniaxial compressive strength on the strength parameters of Mohr-Coulomb failure criterion $\varphi$ and $c$. The input value of angle of internal friction is $\varphi=35^{\circ}$. The value of cohesion was determined as $c=187 \mathrm{kPa}$ using equation (4).

$$
c=\sqrt{\frac{\sigma_{c}}{100}}
$$

Contact between the outer surface of the virtual wall and the surrounding soil was modelled by a contact element with the value of parameter $R_{\text {inter }}=0.75$.

\subsection{Modelling of the Geocell Mattress}

The geocell filled with crushed stone was modelled as a layer with equivalent strength and stiffness parameters. The input values of the strength and stiffness parameter of equivalent material were determined according to [6], [7], and [8], considering the beaviour of crushed stone to be governed by the Duncan-Chang non-linear constitutive model [9]. Increasing of the values of the strength and deformation parameters of the filling material is considered due to the $3 \mathrm{D}$ stress state in the individual cell pocket [10]. The development of the apparent cohesion $c_{r}$ depends on the increased lateral stress $\Delta_{\sigma 3}$ arising in the soil inside the cell due to the membrane stress induced by the wall of the cell. The relationship between the apparent cohesion $c_{r}$ and the lateral stress $\Delta_{\sigma 3}$ is illustrated in Figure 3

The smallest circle illustrates the failure stress state of the unreinforced filling material. The lateral stress $\sigma_{3}$ increases to the value $\sigma_{3}+\Delta_{\sigma 3}$ due to the confinement of the filling material by the cell wall. The value of major principal stress $\sigma_{1}$ increases also from the value $\sigma_{1 u}$. This stress state is illustrated by the circle named "with confinement" in Figure 3 However, the same stress state can also be described by the largest circle, which is determined by the lateral stress $\sigma_{3}$ and the apparent cohesion $c_{r}$. The relationship between $c_{r}$ and $\sigma_{3}$ can be derived using Mohr-Coulomb failure theory. The major principal stress $\sigma_{1}$ is stress that the soil is able to sustain before failure, and can be described by equation (5).

$\sigma_{1}=\frac{1+\sin \varphi}{1-\sin \varphi} \sigma_{3}+2 c_{r} \sqrt{\frac{1+\sin \varphi}{1-\sin \varphi}}=K_{p} \sigma_{3}+2 c_{r} \sqrt{K_{p}}$

Where $K_{p}$ is the passive earth pressure coefficient of the filling material. If the confining pressure $\sigma_{3}+\Delta_{\sigma_{3}}$ is applied to such material, then the $\sigma_{1}$ is given by the equation 6

$$
\sigma_{1}=K_{p}\left(\sigma_{3}+\Delta_{\sigma_{3}}\right)
$$

However, the value of $\sigma_{1}$ stays unchanged. The increment in the apparent cohesion $c_{r}$ due to the increase of the confining pressure can be expressed from the comparison of equations (5) and (6), which results in formula (7).

$$
c_{r}=\frac{\Delta_{\sigma_{3}}}{2} \sqrt{K_{p}}
$$

Increase in the confining pressure $\Delta_{\sigma_{3}}$ on the soil due to the presence of geocell is given by equation (8), which originates in the membrane theory proposed by 12 .

$$
\Delta_{\sigma_{3}}=\frac{2 M}{d_{0}}\left[\frac{1-\sqrt{1-\xi_{a}}}{1-\xi_{a}}\right]
$$

Where $M$ is the secant modulus of the geocell material at axial strain $\xi_{a}$, which is obtained from the tensile load-strain response of the geocell material at $2 \%$ axial strain, and $d_{0}$ is the equivalent diameter of the geocell pocket. The stiffness of the composite material depends on the stiffness of the filling material and on the secant modulus of the geocell material. The nonlinear relationship between these two parameters and between the parameter $K_{r}$ can be expressed by the equation $(9)$.

$$
K_{r}=K_{e}+200 M^{0.16}
$$

In the above $K_{e}$ is the modulus number, which is a dimensionless parameter that represents Young's modulus of the filling material [9].

The elastic modulus of the Duncan-Chang model in loading conditions $E_{i}$ is given by equation 10 , where $n$ is a modulus exponent and $P_{t}$ is the atmospheric pressure which is used to normalise the stress inputs.

$$
E_{i}=K_{r} P_{a}\left(\frac{\sigma_{3}}{P_{a}}\right)^{n}
$$




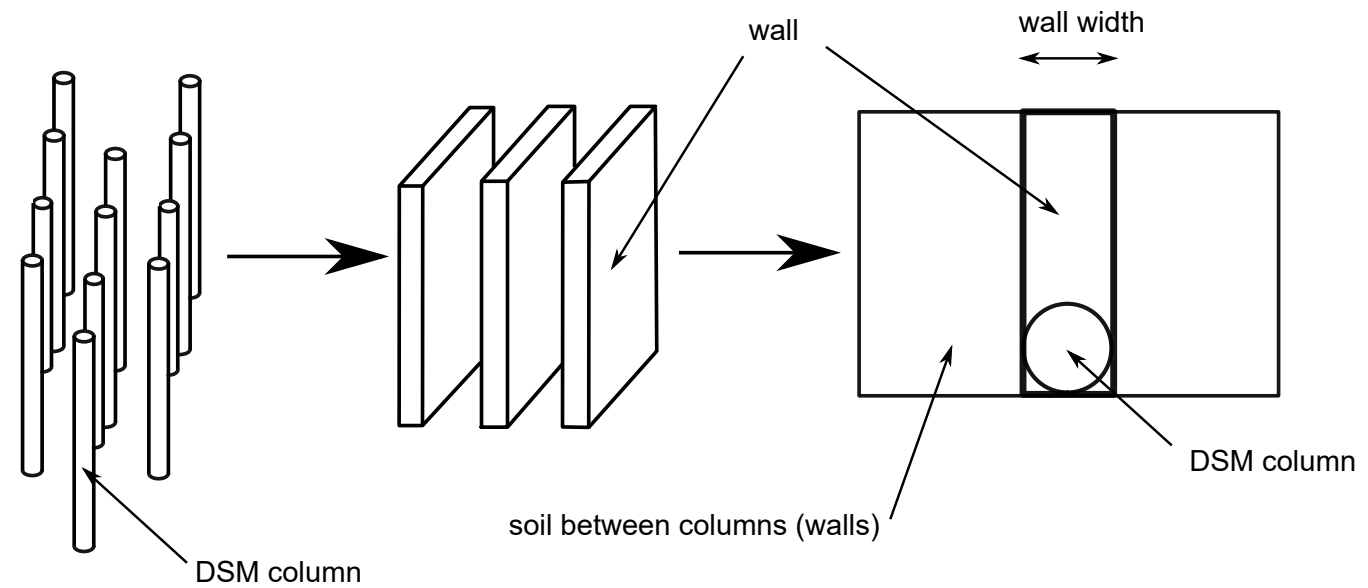

FIGURE 2. The principle of replacing DSM pillars in a plain strain model by a virtual wall. Adapted from 4 .

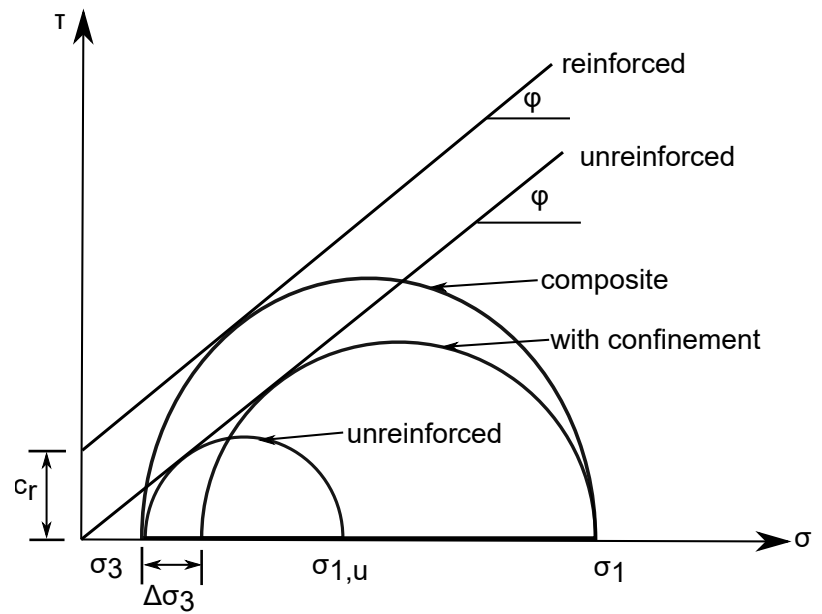

FiguRE 3. Mohr circles for unreinforced, reinforced and composite (geocell filled with crushed stone) material (Adapted after [1])

The values $M=450 \mathrm{MPa}, d_{0}=0.24 \mathrm{~m}, K_{e}=725$, $n=0.43$ and $K_{p}=3$ were used in this presented analysis. The contact between the equivalent geocell layer and the surrounding soil was modelled by a contact element with the value of parameter $R_{\text {inter }}=1.0$ according to the results of experiments published in 13 .

The gabion walls constructed on both sides of the embankment were also included in the model. The gabion baskets were modelled by the "geogrid" type of finite elements. The mechanical parameters of the welded gabion basket net made of steel wire of diameter $=3.0 \mathrm{~mm}$ and wire spacing of $75 \mathrm{~mm}$ were determined according to [14. The value of axial stiffness of the net was $E A=19.0 \mathrm{E} 3 \mathrm{kN} / \mathrm{m}$. The contact between the basket net and the filling material and the wall backfill material was modelled by a contact element with the parameter $R_{\text {inter }}=0.75$. The geogrid element with stiffness $E A=12.9 \mathrm{E} 3 \mathrm{kN} / \mathrm{m}$ was used also for modelling the hi-strength geogrid placed above the heads of the DSM columns. The $60.0 \mathrm{~m} \times 36.0 \mathrm{~m}$ model with 48172 finite elements was used for analysis. The detailed cutout of the FE model with all proposed remediation measures is shown in the Figure 4 The Elastic-perfectly plastic Mohr Coulomb (MC) constitutive model was used to describe the behavior of soil and composite materials. Input values of the MC model are summarised in Table1

\section{LABORATORY TESTING OF DSM COMPOSITE MATERIAL}

Some of the design assumptions stated above were evaluated by execution of laboratory tests. Preproduction laboratory tests were conducted due to the uncertainities in the chemical reactions in the cementsoil mixture, because the slag by-products was added into the embankment during its construction. Mixtures for these tests were prepared according to the recommended procedures described in detail in [15], [16]. Three variants of the mixture were prepared from the soil taken from the embankment during investigation and from a cement suspension. Cement content in suspension varied between $250 \mathrm{~kg} \mathrm{~m}^{-3}$ to $350 \mathrm{~kg} \mathrm{~m}^{-3}$. Water to cement ratio was varied between $\mathrm{w} / \mathrm{c}=0.85$ to 1.3 . The uniaxial compressive strength of the composite material produced by the DSM technology was measured. The compressive strength was determined by placing cylindrical specimens of known dimensions in a test press and loading them at a rate of $1 \%$ of the sample height per minute until failure. The reduction of the resulting strength due to the ratio of the length of the speciment to its height was performed according to [15] to normalise the results of tests performed on samples with a different geometry. The laboratory testing programme follows with an evaluation of the uniaxial compressive strength of the samples taken in-situ. These control tests were performed on the samples prepared from the mixture taken on site directly from the fresh column and cured in laboratory conditions. The second type of samples for control test were prepared from the borehole cores taken from the colums which had already reached a certain strength. The uniaxial compressive strength was evaluated on the 7,21 and 28 days old specimens. The mean value of a uniaxial compressive strength of 


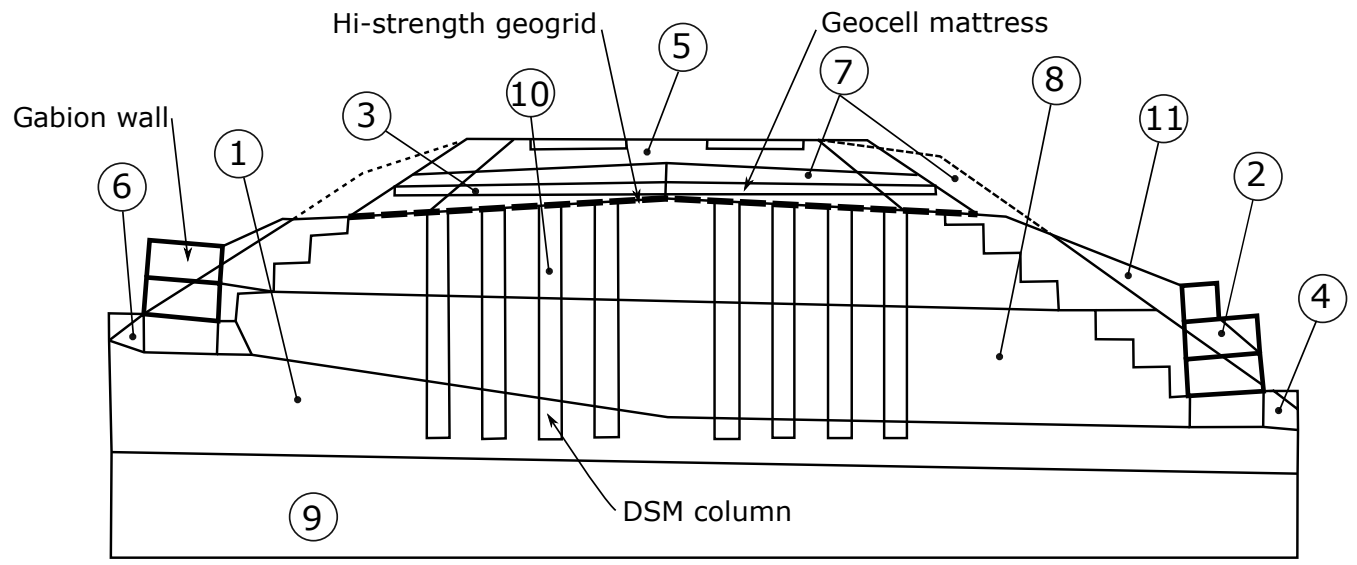

Figure 4. Cutout of the FEM model - detail of the embankment. (The numbers in circles refer to the material characteristics summarised in Table (1)).

\begin{tabular}{lccccccc}
\hline & Material & Unit weights & Strength par. & Deformation par. \\
\hline & & $\begin{array}{c}\gamma_{\text {unsat }} \\
{\left[\mathrm{kN} / \mathrm{m}^{3}\right]}\end{array}$ & $\begin{array}{c}\gamma_{\text {sat }} \\
{\left[\mathrm{kN} / \mathrm{m}^{3}\right]}\end{array}$ & $\begin{array}{c}\mathrm{c}^{\prime} \\
{[\mathrm{kPa}]}\end{array}$ & $\begin{array}{c}\varphi^{\prime} \\
{\left[{ }^{\circ}\right]}\end{array}$ & $\begin{array}{c}\mathrm{E}^{\prime} \\
{[\mathrm{MPa}]}\end{array}$ & $\begin{array}{c}\nu^{\prime} \\
{[-]}\end{array}$ \\
\hline 1 & 18.5 & 20 & 4 & 30 & 11.89 & 0.3 \\
\hline 2 & Gabion infilling rock & 17.9 & 19.6 & 100 & 35 & 20 & 0.2 \\
\hline 3 & Geocell mattress & 17.5 & 19.0 & 33 & 30 & 80 & 0.3 \\
\hline 4 & Silty gravel & 19.00 & 20.50 & 3 & 35 & 26 & 0.3 \\
\hline 5 & Ballast & 20.00 & 22.00 & 1 & 40 & 135 & 0.25 \\
\hline 6 & Fills & 17.00 & 18.00 & 4 & 30 & 8.9 & 0.3 \\
\hline 7 & Embankment - upper part & 17.50 & 19.00 & 1 & 35 & 80 & 0.25 \\
\hline 8 & Embankment - lower part & 17.50 & 19.00 & 2.8 & 30 & 3.13 & 0.28 \\
\hline 9 & Weathered rock in subgrade & 28.00 & 28.00 & 5600 & 39.5 & 600 & 0.25 \\
\hline 10 & DSM columns & 20 & 21 & 187 & 35 & 844 & 0.3 \\
\hline 11 & Backfill & 17.50 & 19.00 & 4 & 32 & 10.4 & 0.3 \\
\hline
\end{tabular}

TABLE 1. Input values of MC constitutive model parameters

the composite was $\sigma_{c}=13.8 \mathrm{MPa}$. Hence, it can be said that the results of numerical analysis are on the safe side.

\section{Results}

The calculated value of the factor of safety was $F=1.09$, when only the self-weight of the embankment was applied to the model of current state of the embankemnt without any proposed remediation measures. This result confirms the in-situ observed situation - the permanent increase of deformations. The implementation of remediation measures increased the calculated factor of safety to the value $F=1.57$. The calculated total deformation of the embankment body will not exceed $13.4 \mathrm{~mm}$ after the reconstruction. The calculated field of total deformations is presented in Figure 5

\section{Conclusions}

The paper describes the evaluation of the design of remediation action at defective railway embankment. The remediation measures consisted of Deep Soil Mixing columns covered by a geocell mattress. The effect of the proposed measures was verified by numerical analysis. The process of building the $2 \mathrm{D}$ numerical model is presented. Results of numerical analysis proved, that the proposed remediation measures leads to a redistribution of the stress field in the embankment body. The stress in the embankment body improved by DSM technique is concentrated in the DSM columns, because they have significantly higher stiffness than the surrounding soil. The largest portion of stress is transmitted by two pillars located closest to center of the embankment body. The laboratory tests are also described, erformed for the purpose of the design and evaluation of the DSM composite material. 


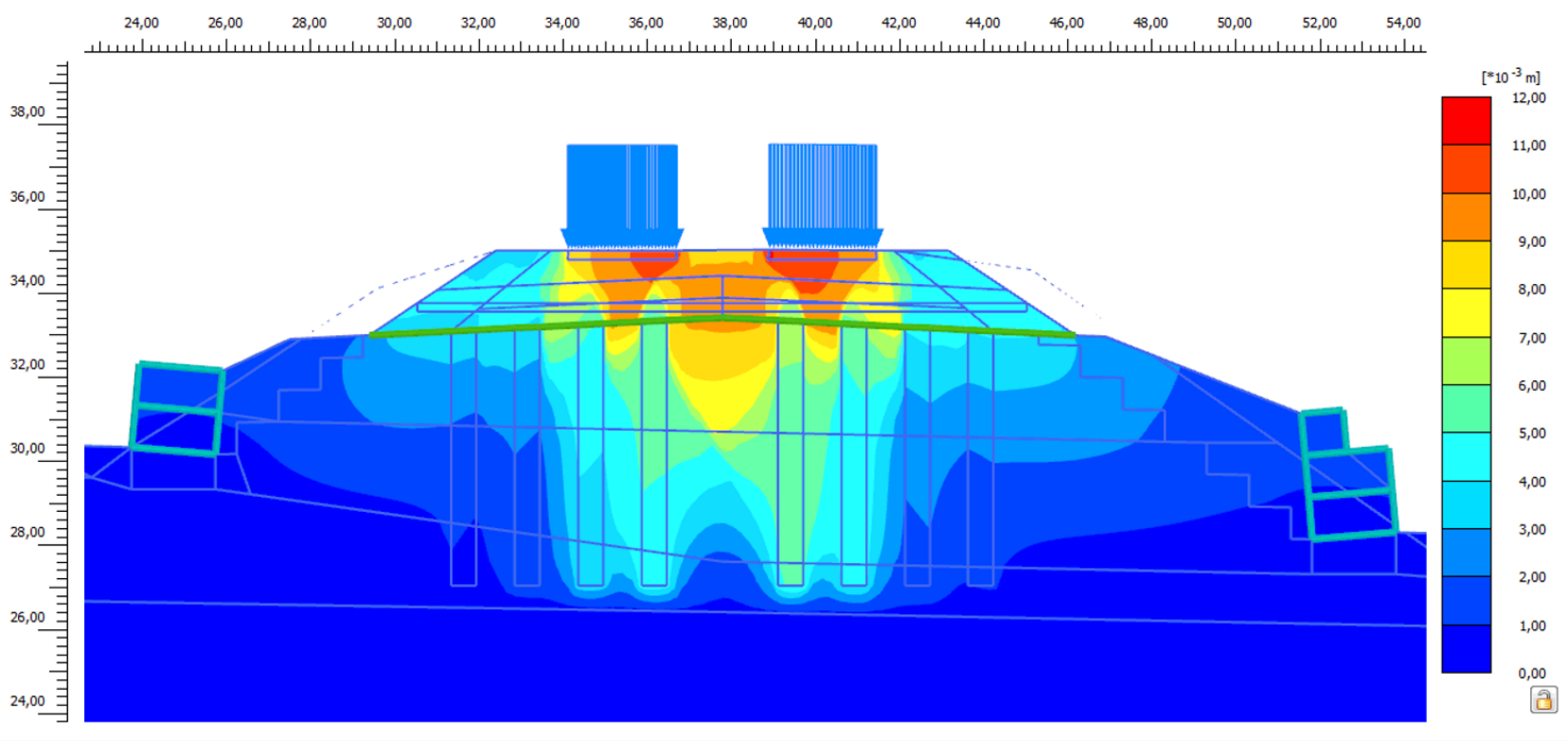

Figure 5. Isolines of computed total deformations caused by a traffic loading of intensity $80 \mathrm{kN} / \mathrm{m}$



Figure 6. Construction of DSM columns at the Ždár nad Sázavou building site

\section{LIST OF SYMBOLS}

$h_{p r}$ Freezing depth $[\mathrm{m}]$

$E_{c o l}$ Modulus of elasticity of DSM column [MPa]

$E_{\text {soil }}$ Modulus of elasticity of soil [MPa]

$E_{e q}$ Modulus of elasticity of virtual wall [MPa]

$A_{\text {col }}$ Cross-sectional area of DSM column $\left[\mathrm{m}^{2}\right]$

$A_{r}$ Cross-sectional area of virtual wall $\left[\mathrm{m}^{2}\right]$ $\sigma_{c} \quad$ Uniaxial compressive strength [MPa]

$\varphi$ Angle of internal friction $\left[{ }^{\circ}\right]$

$c$ Cohesion $[\mathrm{kPa}]$

$c_{r}$ Apparent cohesion $[\mathrm{kPa}]$

$\Delta_{\sigma_{3}}$ Lateral stress increment $[\mathrm{kPa}]$

$\sigma_{3}$ Minor principal stress $[\mathrm{kPa}]$

$\sigma_{1}$ Major principal stress $[\mathrm{kPa}]$

$\sigma_{1 u}$ Major principal stress in unreinforced material $[\mathrm{kPa}]$

$M$ Secant modulus of the geocell material [MPa]

$d_{\mathrm{o}}$ Equivalent diameter of the geocell pocket $[\mathrm{m}]$

$E_{i} \quad$ Elastic modulus in loading conditions $[\mathrm{MPa}]$

$P_{t} \quad$ Atmospheric pressure $[\mathrm{kPa}]$

$R_{\text {inter }}$ Interface strength

$K_{p}$ Passive earth pressure coefficient

$\xi_{a} \quad$ Axial strain

$K_{r}$ Modulus number of reinforced material

$K_{e}$ Modulus number of unreinforced material

$n$ Modulus exponent

\section{ACKNOWLEDGEMENTS}

This work was funded by the research project No. TA04031092 supported by the Technology Agency of the Czech Republic.

\section{REFERENCES}

[1] J. Vašina. Kolejové úpravy v žst. Žd'ár nad Sázavou Technická zpráva (Remediation of the Railway near the station Žd'ár nad Sázavou - Technical report, in czech). Waltec GDS, s.r.o., Blansko, Czech republic, 2019.

[2] P. Řezníček, K. Zdražil, D. Relich, L. Miča. Metodika použití zkoušek statické penetrace CPT a těžké dynamické penetrace DPH při inženýrskogeologických prüzkumech pro dopravni stavby a při jejich výstavbě. (Methodics of implementation of the Cone Penetration Test CPT and Heavy Dynamic Penetration test DPH in engineering-geology investigation and building process of 
traffic structures; in Czech). Technological Agency of the Czech Republic, Brno, Czech Republic, 2017.

[3] P. Svoboda. Hloubkové zlepšování zemin v české praxi (Practical experience with Deep ground improvement methods in the Czech republic; in czech. Akademické nakladatelství CERM, Brno, 1st edn., 2009.

[4] C. M. Tatarniuk. Deep Soil Mixing as a Slope Stabilization Technique in Northland Allochthon Residual Clay Soil - PhD Thesis. University of Canterbury, Christchurch, New Zealand, 2014.

[5] D. H. Ardiaca. Mohr-coulomb parameters for modelling of concrete structures. PLAXIS Bulletin pp. 12-15, 2009.

[6] A. Hedge, S. G. Thallak. Experimental and numerical studies on geocell reinforced sand beds. In Proceedings of Geosynthetics 2013, pp. 119-126. Long Beach, California, USA, 2013.

[7] S. K. Dash, G. M. Latha, K. Rajagopal. Numerical modelling of geocell reinforced soil foundations. In Proceedings of International Congress on Computational Mechanics and Simulation, ICCMS 06At, pp. 1-4. Guwahati, India, 2006.

[8] G. M. Latha, S. K. Dash, K. Rajagopal. Equivalent continuum simulations of geocell reinforced sand beds supporting strip footings. Geotechnical and Geological Engineering 26(4):387-398, 2008. https://doi.org/10.1007/s10706-008-9176-5.

[9] J. M. Duncan, C. Y. Chang. Nonlinear analysis of stress and strain in soils. Journal of Soil Mechanics \& Foundations div 96(5):1629-1653, 1970.
[10] P. Punetha, S. Nimbalkar, H. Khabbaz. Evaluation of additional confinement for three-dimensional geoinclusions under general stress state. Canadian Geotechnical Journal 57(3):453-461, 2020. https://doi.org/10.1139/cgj-2018-0866

[11] K. Rajagopal, N. Krishnaswamy. Behaviour of sand confined with single and multiple geocells. Geotextiles and Geomembranes 17(3), 1999. https://doi.org/10.1016/S0266-1144(98)00034-X.

[12] D. J. Henkel, G. D. Gilbert. The efect of the rubber membrane on the measured triaxial compression strength of clay samples. Geotechnique 3(1):20-29, 1952

[13] L. G. Madhavi, R. Karpurapu, N. R. Krishnaswamy. Interfacial friction properties of geocell reinforced soil. In ISRM International Symposium, 19-24 November, pp. 1-6. International Society for Rock Mechanics and Rock Engineering, Melbourne, Australia, 2000.

[14] M. Ćwirko, M. Jastrzębska, S. Kwiecień. The analysis of the usefulness of welded meshes to embankment reinforcement. Studia Geotechnica et Mechanica 39(3):3-9, 2017-09-1. https://doi.org/10.1515/sgem-2017-0024.

[15] B. C. M. Ellen, R. R. Berg, J. G. Collin, et al. Federal Highway Administration Design Manual. Office of Transportation Management Federal Highway Administration, 400 7th Street SW Washington, DC 20590, 2013.

[16] M. Kitazume, M. Terashi. The Deep Mixing Method. CRC Press/Balkema, EH, Leiden,The Netherlands, 2013. 